\title{
THE RISE AND GROWTH OF SERBIAN BANKING UNTIL WORLD WAR I** Part Three: Serbian Banking System - Operations and Relations of the Private Banks and the National Bank (1878-1914)
}

The development of Serbian banking during the $19^{\text {th }}$ century was a gradual process that underwent two distinctive stages with the turning point in 1878 when Serbia became an independent state by the international agreement concluded at the Berlin Congress.

During the second stage, after 1878, a decisive programme of economic development and modernization resulted in the mushrooming growth of banks and creation of the national banking system that consisted of the Privileged National Bank of the Kingdom of Serbia (National Bank) as a bank of note issue, private banks, state banks and farm cooperative societies. The majority of private banks were small joint-stock unit and universal banks which developed basic banking (discounting, savings deposits, passive and active current accounts, cashless payments, lombard credits, trade in securities) and non-banking activities (establishment of industrial firms and conducting domestic and foreign trade).

Relations between banks and the National Bank had been intensified until 1908 on voluntary basis, primarily by the National Bank's everyday credit operations, undertaken rules and measures. From 1908, however, these relations were regulated by the new Act on the National Bank (1908) through the instrument of interest rate ceiling (Article 6e) and thus became obligatory for both parties. Unfortunately, implementation of this new instrument led to deteriorating of relations between the banks and the National Bank, thus preventing the National Bank to continue with strengthening its role as a central bank.

The Serbian National Bank succeeded in achieving two main aims of a central bank - monetary stability and helping in development of national trade and production, particularly industry. However, it was limited in achieving stability of the banking system

\footnotetext{
* Prof. Biljana Stojanović, PhD, Faculty of Geoeconomics, John Naisbitt University, Belgrade, Serbia, e-mail: bstojanovic@naisbitt.edu.rs

** This paper was originally prepared and presented in the English language on XV World Economic History Congress, held in Utrecht, the Netherlands, from 3 to 7 August, 2009.
} 
because it could not fully perform its lender of the last resort function. This function was constrained, not by unwillingness or incapability of the National bank, but by its two legal obligations - to maintain legal cover and to respect limited issue of the silver notes, i.e. credits in silver. Thus, two systemic banking crises that took place in 1908 and 1912 were successfully managed by the concerted actions of the National Bank and the Serbian state.

Key words: banks, National Bank, national banking system, discount rates, lender of the last resort.

\section{Introduction - National Banking Systems in the $19^{\text {th }}$ century}

Formation of the national banking systems was a process that took place during the $19^{\text {th }}$ century in the majority of independent countries of the world. Nature, structures and main characteristics of banking systems varied across countries depending, on one side, on the level of economic, banking and institutional development, and, on the other, on the notion about the necessity to have one central monetary institution, i.e. central bank. Actually, there were two distinct banking systems - free banking system without the central bank and central banking system. Free banking system existed in the USA from 1830s on the state level, from 1863-4 on the federal level too, up until 1913 when the Federal Reserve System was created as a national central monetary institution. ${ }^{1}$ By the beginning of the $20^{\text {th }}$ century, most countries have finally decided in favour of a central banking system. ${ }^{2}$ In 1883 central bank was also created in the Kingdom of Serbia under the name Privileged National Bank of the Kingdom of Serbia (National Bank) that started its operations from 1884. According to some estimates, there were 18 central banks in 1900 and 20 in $1910 .^{3}$

Although national banking systems greatly differed, one feature was common for all of them - ever increasing government role in regulating the banking sector. Governments were shaping the banking systems with various measures and regulations - from defining the specie content of the national currency, through setting the rules under which commercial banks and central bank could operate to the direct engagements in rescue operations during the banking crisis. Maintaining stability of the national currency and banking system was the main motive of the government intervention during $19^{\text {th }}$ century, although in previous centuries fiscal reasons (especially to finance wars) were also important motives.

1 Grossman, S.R., (2010): Unsettled Account, The Evolution of Banking in the Industrialized World since 1800, Princeton University Press, Princeton and Oxford, p.230.

2 Smith, V. (1990): The Rationale of Central Banking and the Free Banking Alternative, Liberty Fund, Indianopolis, ISBN 0-86597-086-6, p. 3.

3 Capie, F., Goodhart, C. and Schnadt, N. (1994): The development of central bankning, in: Capie, F. et al. (eds.), The Future of central banking: the tercentenary symposium of the Bank of England, Cambrodge UK: Cambridge University Press, pp.1-261, ISBN 9780521496346, p. 6. 
This became obvious from the evolution of some oldest central banks - Bank of England (1694) and Banque de France (1800) both of which were established with the main purpose to help governments to finance wars. In the course of time, with special privileges given by charters or enacted by parliamentary acts, governments trusted the responsibility of monetary and financial stability to one institution - the central bank. Apart from these two original aims, central banks in some countries got the task to help in creating favourable monetary conditions for economic development. This was the case with the Serbian National Bank that was established with the main purpose to provide cheap credits to help the development of trade and production. ${ }^{4}$

Central banks in the metal monetary standards of the $19^{\text {th }}$ century (monometallism of gold or silver and bimetallism) used several main instruments to achieve their three primary aims. For maintaining stability of the national currency, unconditional and unlimited convertibility of the banknotes had been the oldest instrument. Later, to that was added the monopoly of the central bank to issue banknotes that were proclaimed the sole legal tender. To maintain the stability of the banking system, central banks assumed the role of the lender of the last resort. Discounting operations, i.e. discount rate policy was not only an instrument for maintaining financial stability by influencing credit activities of the banks, but also an instrument for stimulating economic growth.

Efficiency of the central bank to achieve these main objectives depended on its influence on commercial banks which, with the innovation of banknotes, became the main creators of money in circulation (taking over this function from the mints). The stronger the relations between the central bank and commercial banks, the more efficient was the central bank's influence on monetary and financial stability. Relations between central banks and commercial banks were primarily established through stimulating commercial banks to keep their deposits, reserves and other balances with the central bank - in some countries by legislation (as a statutory balances - USA) and in others, by central banks' own rules (non-statutory balances - Kingdom of Serbia). ${ }^{5}$ Due to this, the central bank became known as bankers' bank. But, governments also kept their deposits and accounts with the central bank which was why the central bank was also known as a government's banker. The history of relations between governments and the central banks is a story of ebb and flow in their closeness (or distance) that determined the extent of the independence of the central bank in defining and applying monetary policy, primarily determining its interest rate. ${ }^{6}$ That governments even in the $19^{\text {th }}$ century, when most todays' central banks were private institutions, intended to influence central banks could be seen from Napoleon's

Zakon o Narodnoj banci, 6. Januar, 1883. god.

Special case is England where there was no direct but indirect relation between Bank of England and commercial banks via the discount houses.

6 Capie, F., Goodhart, C. and Schnadt, N. (1994): p. 50, 52.

Vol. 14, № 2, 2017: 1-22 
words about than newly established Banque de France: "I want the bank to be more in the hands of the government but not too much."7

Rescue of the troubled banks had been a regular activity from the earliest banking crises. In the beginning, rescue operations were performed, individually or jointly, by the governments, sound, healthy banks, clearing houses and finally central banks. There were two main kinds of rescues - bailouts, for saving individual weak banks, and lender of the last resort operation, for saving the whole banking and economic system. ${ }^{8}$ The main activity in both rescue operations was infusion of additional liquidity into the troubled bank or banking system in times of liquidity squeeze.

Francis Baring introduced the term lender of the last resort into monetary theory in his writing on the Bank of England at the end of the $18^{\text {th }}$ century. ${ }^{9}$ The ideal form of the lender of the last resort was defined firstly by Henry Thornton in his Paper Credit (1802) and later by Walter Bagehot in his Lombard Street $(1873)^{10}$. This ideal form excludes individual bailouts and means to lend unlimited amounts to any institution but backed by good-quality paper on a penalty rate, preferably in an anonymous fashion. Defined in this way, the lender of the last resort operation minimizes moral hazard that is always present in bailouts. While bailouts prevented bankruptcies of individual banks in order to prevent "domino effect" on other banks, the lender of the last resort operation contained already existing widespread banking crisis featured by the collapse of the money stock and high market interest rates, which threatened to lead to economic downfall and unemployment.

By about 1900, lender of the last resort operation was widely accepted as a core function of the newly established central bank. ${ }^{11}$ Also, monetary literature defined fully-fledged central bank by this function and monopoly of note issue (Table 1).

According to criteria in Table 1, the first fully-fledged central bank was the Belgian National Bank that was established in 1850 with monopoly of note issue and power of the lender of the last resort. Among presented central banks, only the Bank of England performed the lender of the last resort function in a completely anonymous fashion through the buffer of the discount houses. ${ }^{12}$ It is

$7 \quad$ Blancheton, B. (2015): Towards a tacit low-degree independence central banking model, Cahiers du GREThA, No 2015-17, Universite de Bordeaux, France, p. 3.

$8 \quad$ Other rescue measures used until 1914 were bank holydays, temporary moratoria on deposit withdrawals, deposit insurance, bank mergers and after the Great Depression nationalization of banks.

9 Capie, F., Goodhart, C. and Schnadt, N. (1994), p.66.

10 Capie, F. (1999): Banking in Europe in the nineteenth century: the role of the central bank, in: Sylla, R., Tilly, R., and Tortella, G., (eds.) The State, the Financial System and Economic Modernization, Cambridge: Cambridge University Press,pp. 118-133, p. 120-123.

11 Capie, F., Goodhart, C. and Schnadt, N. (1994): p.65.

12 Capie, F. (1999): p.125. 
interesting that Serbian National Bank was excluded from this group of the central banks although it was established with the monopoly of note issue.

The structure of the Serbian banking system that consisted of the National Bank, numerous private banks, state banks and farm cooperative societies is presented in part two of the paper about the development of Serbian banking. ${ }^{13}$ The aim of this third part of the paper is to present the functioning of the Serbian banking system until 1914. The first section of the paper presents private banks' operations, the second section deals with the relations between the National bank and private banks and the third section deals more thoroughly with the National Bank's credits. The analysis will examine to what extent the National Bank performed the main central bank functions - especially lender of the last resort function which will shed more light on the question why it is excluded from the group of fully-fledged central banks in Table 1.

Table 1. Central banking institutions before $1900^{*}$

\begin{tabular}{|c|c|c|c|}
\hline Bank & Established - Year & $\begin{array}{c}\text { Monopoly of note issue } \\
- \text { Year }\end{array}$ & LLR* - decade \\
\hline Sverige Riksbank & 1668 & 1897 & 1890 \\
\hline Bank of England & 1694 & 1844 & 1870 \\
\hline Banque de France & 1800 & 1848 & 1880 \\
\hline Bank of Finland & 1811 & 1886 & 1890 \\
\hline Nederlandsche Bank & 1814 & 1863 & 1870 \\
\hline Austrian National Bank & 1816 & 1816 & 1870 \\
\hline Norges bank & 1816 & 1818 & 1890 \\
\hline Danmarks Nationalbank & 1818 & 1818 & 1880 \\
\hline Banco de Portugal & 1846 & 1888 & 1870 \\
\hline Belgian National Bank & 1850 & 1850 & 1910 \\
\hline Banco de Espana & 1874 & 1874 & 1880 \\
\hline Reichsbank & 1876 & 1876 & 1880 \\
\hline Bank of Japan & 1882 & 1883 & 1880 \\
\hline Banca D'Italia & 1893 & 1926 & \\
\hline
\end{tabular}

${ }^{*}$ The table excludes central banking institutions of the Netherlands Antilles (est.1828), Indonesia (1828), Bulgaria (1879), Romania (1880) and Serbia (1883).

${ }^{*}$ LLR $=$ Lender of the last resort

Source: Capie, F., Goodhart, C. and Schnadt, N. (1994), p. 6.

13 Stojanović, B. (2017): The rise and growth of Serbian banking until World War I, Part Two: The Second stage - The National State and the Nationala Banking, Megatrend revija/ Megatrend Review, Vol 14 (1). 


\section{Operations of the Private Serbian Banks}

Business operations of the private Serbian banks were classified in the literature of the time into three categories: passive, active and neutral. The passive operations were those on the liabilities side of the bank's balance sheet, active on the asset side and neutral were payment services done on behalf of the customers.

\subsection{Passive Operations}

Since the right to issue notes was an exclusive privilege reserved only for the National Bank, the passive operations of other banks included three main operations:

1. savings deposits

2. checking accounts

3. passive current accounts.

All Serbian banks, except the National bank, were dealing in savings deposits. Data show that in 1895 , total savings deposits of the private banks amounted to 12,3 million dinars of which 5,1 million dinars were held by the banks in Belgrade. ${ }^{4}$ The same year, banks were paying different interest on savings deposits ranging from $4 \%$ to $9 \% .{ }^{15}$

Taking savings deposits was the most important operation of the private banks by which they raised financial potential above the modest amount of their paid-up capital. ${ }^{16}$ The rise of savings deposits and paid - up capital and difference between them are shown in Table 2 .

Table 2. Savings deposits and paid-up capital of Serbian private banks 1900-12 in mill. dinars

\begin{tabular}{|c|c|c|c|c|c|c|c|c|c|c|c|c|c|}
\hline Year & ஜั & ळু & જ̊ & ஜ̊ & ষัণ & ஜ̊ & ஜั & 옹 & ڤ̊ำ & 옹 & $\frac{0}{9}$ & हू & $\frac{\pi}{2}$ \\
\hline $\begin{array}{l}\text { Savings } \\
\text { deposits }\end{array}$ & 20,8 & 21,8 & 21,4 & 23,0 & 27,8 & 31,0 & 35,2 & 39,5 & 35,0 & - & 54,5 & 65,0 & 65,0 \\
\hline $\begin{array}{c}\text { Paid-up } \\
\text { capital }\end{array}$ & 16,7 & 18,3 & 19,9 & - & 22,9 & 24,5 & 24,0 & 27,9 & 32,2 & 33,5 & 45,7 & 45,8 & 51,2 \\
\hline
\end{tabular}

Source: Stojanović, B. (2017).

\footnotetext{
14 Narodna banka 1884-1934, (1934): Zavod za izradu novčanica Topčider, p.28.

15 Ibid.

16 Banks and other joint-stock companies in the $19^{\text {th }}$ century had an "authorized" (also called "nominal") capital that represented the amount of share capital permitted to be issued under the terms of its incorporation. Of this amount, very often only a portion would be really "paid in" or "paid up" at the time of company's formation.
} 
As it is seen, during the whole period savings deposits were higher than paid-up capital. Steady growth of savings deposits was disrupted only twice - in 1908 (when they decreased) and in 1912 (when they stagnated) due to systemic banking crises in those years. In 1912, total savings deposits were 65 million dinars against total paid-up capital of 51,2 million dinars.

Although savings deposits rose more than five times between 1895 and 1912 , according to some estimates of the time, the level of savings deposits in Serbian banks was insufficient to meet ever rising demand for money and capital due to several reasons. One strong reason was the habit of population to hoard money and spend it on luxury goods, the latter particularly by the city dwellers. There was also no significant attempt to promote the importance of savings, neither from the banks' part, nor the public authorities. On the contrary, the state imposed the tax of $16,60 \%$ on the banks that had to be paid on interest earned by their customers on the savings accounts, which discouraged banks to increase savings deposits at a more rapid pace. ${ }^{17}$

Yet another state measure - the annual obligation of banks to pay dues of 10 dinars on every checking account, discouraged development of checking accounts and cashless money transfers. Serbian merchants themselves hindered this banking operation by preferring cash payments in their business. Thus, big sums of money were excluded from productive use, lying idle in private hoards or in merchants' cash desks, instead of being put in banks for the benefit of the country's banking and economic growth.

Table 3. Passive Current Accounts of the banks in 1911 and 1912 in mill. dinars

\begin{tabular}{|c|c|c|c|}
\hline Year & Belgrade banks & Provincial banks & Total \\
\hline 1911 & 41,56 & 17,11 & 58,68 \\
\hline 1912 & 81,84 & 20,40 & 102,25 \\
\hline
\end{tabular}

Source: Kukla (1924), p. 46.

To mobilize additional financial resources, banks developed the practice to raise credits with various other monetary institutions - the National Bank, domestic banks and foreign banks in Serbia and abroad. These credits were recorded in banks' balance sheets as passive current accounts.

Data from Table 3 show that total credits raised by the banks were 58,68 million dinars in 1911 which was the amount higher than total paid-up capital $(45,8$ million dinars) but lower than savings deposits (65,0 million dinars) of that year. ${ }^{18}$ However, credits doubled in 1912 to 102,25 million dinars. Remarkable

$17 \quad$ Kukla, S. (1924): Razvitak kreditne organizacije u Srbiji do svetskog rata, Komisiona naklada Hr. Štamp. Zavod D.D., Zagreb, p. 45.

18 Stojanović, B. (2017): p. 10.

Vol. 14, № 2, 2017: 1-22 
rise of these credits in 1912 was facilitated by the entry of the foreign banks in Serbia that advanced considerable loans to domestic banks in order to exploit extraordinary high investment opportunities that prevailed in Serbia throughout 1910 and 1911. Thus in 1912, passive current accounts, i.e. credits raised by the banks, became the most important source of banks' financial potential since the total savings accounts that year stagnated at 65 million dinars and paid-up capital was 51,2 million dinars. ${ }^{19}$

\subsection{Active Operations}

Serbian banks developed various kinds of active operations. These operations could be classified into several main categories:

1. discounting bills of exchange

2. active current accounts

3. establishment of industrial firms

4. domestic and foreign trade

5. lombard operations

6. trade in securities

In the beginning, discounting bills of exchange was the foremost banking operation in all Serbian banks. During the $19^{\text {th }}$ century, discounting was dominant business of commercial banks all over the world. ${ }^{20}$ At that time, buying real bills with maturity of 90 days was the best way for banks to maintain both - liquidity and solvency since the bills from their portfolios could be sold - rediscounted on the secondary money market in times of liquidity squeeze. Thus, discounting real bills was maintained as the optimal banking strategy that was also accepted in Serbia. But, in $19^{\text {th }}$ century Serbia, the bills were not high quality papers as in a more advanced countries - they were less secure to be paid on maturity. In such a case they were usually prolonged and substituted on maturity by the new bills. ${ }^{21}$

The National Bank was strongly against this practice of prolonging the bills of exchange because it tended to jeopardize monetary stability and was not compatible with the modern practice of discounting in other countries at that time. ${ }^{22}$ On its part, the National Bank refused to rediscount prolonged and uncertain bills. It discounted only prime bills with 92 days maturity issued by merchants and industrialists and very rarely bills issued by banks. In 1886, however, the National Bank introduced the new method of advancing loans to the banks - collateralized loan. This loan was known as active current account since it was done by opening current account to the private bank with its obligation to pledge col-

\footnotetext{
$19 \quad$ Ibid.

20 Ćirović, M., (2001): Bankarstvo, Bridge Company, Beograd, p. 44.

$21 \quad$ Stanarević, Nik. (1912): Beogradske banke u 1911, Štamparija Sv. Sava, Beograd, p. 17.

22 Godišnji izveštaj Privilegovane Narodne Banke Kraljevine Srbije, (1885): p. 8.
} 
lateral in the bills of exchange. The amount of the loan had to have $125 \%$ cover in the bills' collateral and could reach the maximum level of the half of the bank's paid-up capital. Later, the National Bank introduced collateralized loans for other clients too - merchants and industrialists but from them it asked higher cover of $133 \%$. From that time on, collateralized loans, or active current accounts, became the exclusive way in which the National Bank advanced loans to the banks.

Following the example of the National Bank, Belgrade banks started to apply the same policies and methods towards their customers. They began to discount only the prime bills and to use more and more collateralized loans in which the bills, as well as other short-term papers and sometimes securities, were accepted as collateral. Data on discounting and active current accounts operations of the banks for 1911 and 1912 years are shown in Table 4 and Table 5.

Table 4. Discounting operations of the Serbian private banks in 1911 and 1912 in mill. dinars

\begin{tabular}{|c|c|c|c|}
\hline Year & Belgrade banks & Provincial banks & Total \\
\hline 1911 & 22,11 & 57,05 & 79,16 \\
\hline 1912 & 25,34 & 58,49 & 83,83 \\
\hline
\end{tabular}

Source: Kukla (1924), p. 37.

It is interesting to note that discounting business was much more developed in the provincial than in Belgrade banks. Data show that active current account operations, or collateralized loans, were the predominant business of the Belgrade banks.

Table 5. Active Current Account of the Serbian private banks in 1911 and 1912 in mill. dinars

\begin{tabular}{|c|c|c|c|}
\hline Year & Belgrade banks & Provincial banks & Total \\
\hline 1911 & 53,32 & 10,71 & 64,14 \\
\hline 1912 & 83,45 & 12,55 & 96,00 \\
\hline
\end{tabular}

Source: Kukla (1924), p. 37.

Besides the bills of exchange, the banks were willing to accept the ownership deeds and other securities as collateral. However, loans were often advanced without any collateral. These unsecured loans were given to the banks' known regular customers, especially well-established merchants, but also to private persons, such as friends of the banks' shareholders or officials and even completely unknown people. In the latter case, it was difficult to get information about the creditworthiness of the borrower since there was no center or institution - clearing house or agency, specialized in collecting, analysing and disbursing information about various business organizations. Even when a bank got some informa- 
tion about the potential borrower, this could not be considered reliable, especially if the informant and borrower did not belong to the same political party.

Similar information problems were common for banks throughout the world in the $19^{\text {th }}$ century. To the question how to judge a potential borrower, advisors of $19^{\text {th }}$ century American banks recommended: "The amount that may be safely loaned... can be ascertained only from an intimate personal acquaintanceship with the borrower and his business or from a study of a balance sheet or financial statements setting forth the conditions of the business." ${ }^{23}$ But, it was not until the 1890s that the use of financial statements became common even in large American banks due to the lack of uniform accounting methods without which financial statements could not be taken as reliable.

Although some economists, as Schumpeter among others, considered bank's direct involvement in establishing, owing and running industrial firms as antithetical to the very nature of commercial banking in a capitalistic system, such instances have been by no means uncommon in banking history, especially in preindustrial economies and those in the early stages of industrialization. Serbia is such an example. Some big Serbian banks invested capital (from paid-up capital and deposits) in setting up many kinds of industrial firms and running them as owners. Among these banks, just to mention a few of them, were: Serbian Credit Bank - owned a leather plant, Turnover Bank - owned the big timber factory, Vračar Savings House - owned Ribarska spa resort, Belgrade Merchant Bank - owned cement plant, Belgrade Cooperative - set up glass factory and handled its exports, Vračar Cooperative - owned a mill, General Economy Bank was the dominant shareholder in Slaughter-house Society from Belgrade etc. ${ }^{24}$

According to some economists, the engagement of Serbian banks in establishing and running industrial firms was of the crucial importance in the first stage of industrial development in Serbia, particularly during the years of Customs war (1906-1911) with far-reaching favourable economic results. One of these results were increasingly high industrial real rates of growth - 16,3\% in 1906 and even reaching up to fantastic 47,3\% in 1911, which contributed to the overall booming economic conditions in the country. ${ }^{25}$ This bright investment climate also draw the attention of the European financial circles and, from 1910, there was a great inflow of foreign capital into Serbian economy and banking.

Serbian banks also engaged themselves in the retail sale of their industrial produce and majority of them in exports and imports in various ways. It could be said that almost every bank, together with the National Bank, was engaged in

\footnotetext{
23 White, E.N. (1998): Were Banks Special Intermediaries in Late Nineteenth Century America?, Federal Reserve Bank of St. Louis, May/June, p. 20.

24 Milić, Dr D., (1994): Monetarno-kreditni sistem u privredi Srbije početkom XX veka, in: Srbija u modernizacijskim procesima XX veka, Institut za noviju istoriju Srbije, Beograd, p. 86

25 Stojanović, B. (1992): Iz ekonomsko-finansijske i političke istorije Srbije (1878-1918), Finansije, broj 3-4, Beograd, p.172.
} 
financing exports. To help the exports, the National Bank advanced extraordinary credits to banks during the export seasons. Some banks directly carried out export of grain, plum, leather and other goods. A number of banks created their own technical departments for the importation of equipment and machinery from Austria-Hungary, Germany and England. Customarily, they were selling imported equipment and machinery by allowing medium-term credits to domestic buyers. These activities were also of great help in the growth of industry.

Banks rarely engaged themselves in lombard operations - particularly credits backed by securities. In 1911 lombard amounted to 14 million dinars and in 1912 decreased to 10,2 million dinars. Also, trading in securities was of a small scale. In 1913 it was just about 1,3 million dinars. The small scale of these operations was not a surprise because money and capital markets were just in their embryonic state although the exchange in Belgrade was opened in $1895 .{ }^{26}$ To stimulate trade in securities, the Ministry of the National Economy prescribed in 1904 that all the banks must invest their reserves in Serbian government securities. ${ }^{27}$

A number of banks were the members of the Belgrade Exchange. On that exchange, banks had the highest turnover on the foreign exchange and currency (coins and banknotes) markets. In 1913, banks' turnover on the foreign exchange market was 13, 5 million dinars and on the currency market even 68,8 million dinars.

Neutral operations of the banks, i.e. executing payments on behalf of their customers, i.e. payment operations, were more developed in foreign than in domestic payments. The majority of provincial businessmen were unaccustomed to keeping their money in the banks and they still preferred to use coins for their payments. Thus, cashless payments were not established except in international transactions. This was reflected in the considerably higher turnover on the currency than foreign exchange market on the Belgrade Exchange as it was already mentioned.

Analyses of the Serbian private banks' main operations showed that banks freely operated banking and non-banking activities. There was no specialization of banks, nor legal separation between commercial and investment banking. Accordingly, until 1914 Serbian private banks were of a universal type as was common feature of banks in many European countries.

\section{Operations between the National Bank and Other Banks}

There was no specific act on banks in the Kingdom of Serbia as was also the case in many other countries in the $19^{\text {th }}$ century. History of banking law showed that the earliest bank regulations were in the form of charters - specific permissions given by the sovereign or legislature body (parliament) to a firm allowing it to

\footnotetext{
$26 \quad$ The Act on the Public Exchange was adopted in 1886.

27 AS, Zbornik zakona, 1904, Zbornik 59, p. 434.
}

Vol. 14, № 2, 2017: 1-22 
undertake banking business. ${ }^{28}$ With the development of banking, individual chartering declined and banks were set up and regulated, explicitly or implicitly, under the already existing company laws. The first special banking acts were introduced in England in 1844 and in Sweden in 1846 representing relatively detailed banking codes that regulated main conditions for operating banking business - rules of entry, minimum standards for capital and requirements to publish balance sheets. ${ }^{29}$

Banking business in Serbia was regulated in the beginning by the Civil Code (1844), later by the Commercial Act (1860) and the Act on Joint-Stock Companies (1896). The Civil Code defined banks as commercial firms which trade in money. ${ }^{30}$ Neither of these three acts regulated relations between banks and the National Bank. Even the Act on the National Bank of 1883 did not tackle this important issue of monetary policy. Nevertheless, these relations gradually developed since the National Bank considered other banks as natural partners in fulfilling its primary role to provide cheap credits to trade and production. ${ }^{31}$ This was explicitly expressed in its annual report for 1890 by the statement that "all banks led by the National Bank constitute credit organization of Serbia"32 In other words, the National Bank considered itself as the central bank and this was evident from its everyday operations, undertaken rules and measures. One of these rules defined its operations and relations with its customers in the document entitled "Rules for doing business with the National Bank" ${ }^{33}$ Unfortunately, this document has not been available so far for examination. However, by its mentioning in various National Bank's annual reports, it is possible to reconstruct in general how these rules regulated credit relations of the National Bank with other banks, constituting the national banking system.

It has been already mentioned that the National Bank advanced credits to other banks exclusively through active current accounts, i.e. by collateralized loans with $125 \%$ cover in the bills of exchange. Every bank could receive the amount of credit up to the half of its paid-up capital with three-month maturity and every three months bank should have applied for prolongation of this credit arrangement.

Apart from these orderly credits, all the banks could count on extraordinary credits from the National Bank in times of liquidity squeeze that regularly appeared during the peaks of export seasons in almost every autumn when demand for credits was at its highest levels. In the beginning, the National bank requested that banks should borrow during liquidity squeeze only from the National Bank,

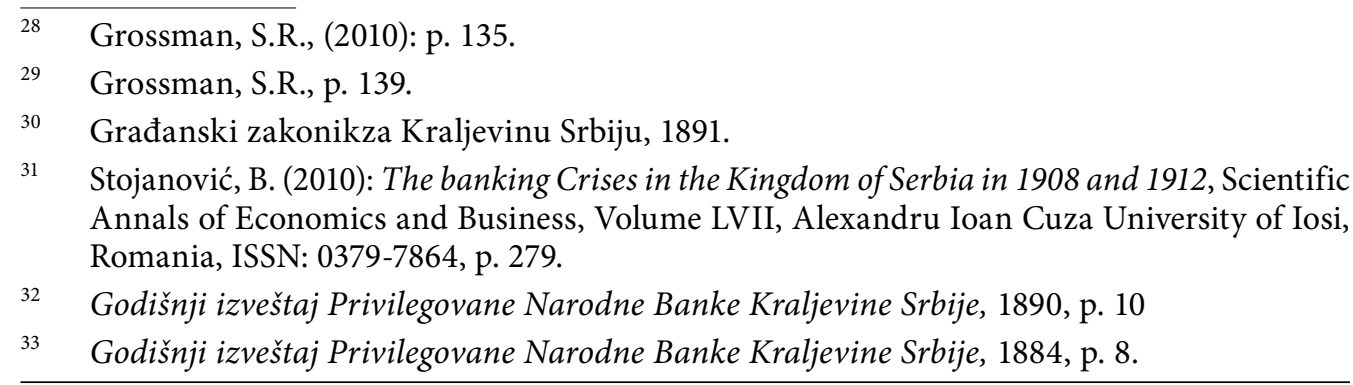


not from any other domestic or foreign bank. ${ }^{34}$ This request suggests that, from the early stage, the National Bank wanted to act as a sole lender of the last resort in the economy. ${ }^{35}$ Later, however, the National bank gave up this request because it could not meet fully the rising demand for money and credit due to two legal obligations - firstly, obligation to maintain the legal cover of $40 \%$ and secondly, obligation to respect the rule of limited issue of the silver notes i.e. credits in silver. Later obligation was introduced by the government in 1893 as a measure against the rising agio and remained current until the World War I. ${ }^{36}$ By these obligations, the National Bank was constrained in its function of the lender of the last resort. This was obvious during two systemic banking crises that took place in 1908 and 1912 characterized by huge withdrawals of savings deposits. Since the National Bank did not have capability of unlimited lending, rescue operations were also taken by the State (Ministry of Finance and Ministry of the National Economy) which helped the National Bank to continue lending in order to contain withdrawals from the banks. Thus, both banking crises were successfully managed by the concerted actions of the National Bank and the Serbian state. ${ }^{37}$

Despite the legal constraints to its lender of the last resort function, the National Bank used other methods and instruments to strengthen its central position in the monetary system. To stimulate as many banks to come to its counters, the National Bank gave privileged status to the banks in its interest rates policy, i.e. lower interest rates than for other customers. In the beginning, only two major banks, Beogradski kreditni zavod and Beogradska zadruga, had the right to raise credits with $1 \%$ lower discount rate than general discount rates, that for other banks and customers. ${ }^{38}$ However, from 1886 up until 1914, discount rates for all private banks were lower by $0,5 \%-1 \%$ than general discount rates (Table 6). But, if the banks were exporters themselves, they could get credits with discount rates lower by $2 \%$ than general discount rates. ${ }^{39}$ For having and maintaining the privilege of lower discount rates, there was one condition - banks had to let the National Bank control their business at any time.

Preferential status given by the National Bank to the banks attracted more and more private banks to work with the National Bank and to accept and avail themselves to its directives and control on a voluntary basis. ${ }^{40}$ This enabled the National Bank to enhance its influence on the banks in their credit and lending rate's policies.

34 Narodna banka 1884-1909, (1909): Štampano u novoj štampariji - Davidović- Ljub. M. Davidovića, Beograd p. 120.

35 Stojanović, B. (2010): p. 280.

$36 \quad$ Narodna banka 1884-1934, (1934): p. 38.

37 Stojanović, B. (2010): p. 287.

$38 \quad$ Narodna banka 1884-1934, (1934): p. 27.

$39 \quad$ Narodna banka 1884-1909, (1909): p.119.

40 Stojanović, B. (2010): p. 279.

Vol. 14, № 2, 2017: 1-22 
Table 6. Discount Rates of the National Bank of Serbia 1884-1914 in \%

\begin{tabular}{|c|c|c|c|c|}
\hline \multirow{2}{*}{ Year } & \multicolumn{2}{|c|}{ General Discount Rate } & \multicolumn{2}{|c|}{ Discount Rate for Banks } \\
\hline & Silver & Gold & Silver & Gold \\
\hline 1884 & $5,5-7,0$ & $5,5-7,0$ & $5,5-7,0$ & $5,5-7,0$ \\
\hline 1885 & $5,0-8,0$ & $5,0-8,0$ & $5,0-8,0$ & $5,0-8,0$ \\
\hline 1886 & $6,5-8,0$ & 8,0 & $5,5-7,5$ & $7,0-7,5$ \\
\hline 1887 & 6,5 & 8,0 & 5,5 & 7,0 \\
\hline 1888 & $6,0-6,5$ & 8,0 & 5,5 & 7,0 \\
\hline 1889 & 6,0 & 8,0 & 5,0 & 7,0 \\
\hline 1890 & 6,0 & 8,0 & 5,0 & 7,0 \\
\hline 1891 & $5,5-6,0$ & $7,5-8,0$ & $4,5-5,0$ & $6,5-7,0$ \\
\hline 1892 & $5,5-6,5$ & $7,5-8,5$ & $4,5-5,5$ & $7,5-8,5$ \\
\hline 1893 & $6,0-6,5$ & $7,5-8,5$ & $5,0-5,5$ & $7,5-8,5$ \\
\hline 1894 & 6,0 & 7,5 & 5,0 & 7,5 \\
\hline 1895 & 6,0 & 7,5 & 5,0 & 7,5 \\
\hline 1896 & 6,0 & 7,5 & 5,0 & 7,5 \\
\hline 1897 & 6,0 & 7,5 & 5,0 & 7,5 \\
\hline 1898 & 6,0 & 7,5 & 5,0 & 7,5 \\
\hline 1899 & 6,0 & 7,5 & 5,0 & 7,5 \\
\hline 1900 & 6,0 & 7,5 & 5,0 & 7,5 \\
\hline 1901 & 6,0 & 7,5 & 5,0 & 7,5 \\
\hline 1902 & 6,0 & 7,5 & 5,0 & 7,5 \\
\hline 1903 & 6,0 & 7,5 & 5,0 & 7,5 \\
\hline 1904 & 6,0 & 7,5 & 5,0 & 7,5 \\
\hline 1905 & 6,0 & $6,0-7,5$ & 5,0 & $5,0-7,5$ \\
\hline 1906 & 6,0 & 6,0 & 5,0 & 5,0 \\
\hline 1907 & 6,0 & 6,0 & 5,0 & 5,0 \\
\hline 1908 & 6,0 & $6,0-8,0$ & 5,0 & $5,0-8,0$ \\
\hline 1909 & 6,0 & 8,0 & 5,0 & 8,0 \\
\hline 1910 & 6,0 & $7,0-8,0$ & 5,0 & $6,0-8,0$ \\
\hline 1911 & 6,0 & $6,0-7,0$ & 5,0 & $5,0-6,0$ \\
\hline 1912 & 6,0 & $6,0-7,0$ & 5,0 & $5,0-6,0$ \\
\hline 1913 & 6,0 & 7,0 & 5,0 & 6,0 \\
\hline 1914 & 6,0 & 7,0 & 5,0 & 6,0 \\
\hline
\end{tabular}

Source: Dugalić (1999): p. 244. 
The National Bank kept its discount rates remarkably stable for the following twenty years (1894-1914) - general discount rate at 6\% (for silver) and discount rate for banks at $5 \%$ (for silver). Only discount rates for credits advanced in notes backed by gold slightly changed - between $5 \%$ and $8 \%$. Such a policy of stable discount rates was a tremendous impetus, not only for banking development, but for the overall economic growth.

In its endeavors to provide cheap money for the economy, in 1891 the National Bank introduced rules for banks regarding their maximum lending interest rates. According to these rules, lending rates of banks older than three years had to be up to $8 \%$; of banks older than two years up to $9 \%$ and of banks that existed only one year up to $10 \%$ per annum. ${ }^{41}$ If banks disobeyed the proposed maximum interest rates, the National Bank would cease to advance them credits. The banks were left free to accept these rules or not, since they did not have legal, obligatory character.

\section{National Bank's credits - Total and to Private Banks}

Many European central banks in the $19^{\text {th }}$ century, such as Banque de France and Reichsbank, were doing business with wider range of customers apart from commercial banks - with industrial firms in particular. ${ }^{42}$ The Serbian National Bank belonged to this group too. It was allowed to advance short-term credits to the State, banks and trade and industrial firms. However, credits advanced to the banks gradually increased in absolute and relative terms (Table 7).

In relative terms, credits to the banks almost tripled - they increased from $23,2 \%$ in 1884 to $62,6 \%$ in 1913 (Figure 1). This pronounced intensification of credit relations with the banks on account of its other customers was a clear evidence of the enhancing role of the National Bank in the monetary system that was gradually strengthening its role as a central bank. In practice, this intensification enabled the National Bank to increase its control over the credit volume of the banks and thus over the monetary stability that was one of its primary aims.

Existing model of the monetary system based on complete freedom in decision-making and autonomy of actions in relations between the National Bank and other banks was changed with the new Act on National Bank adopted in 1908. This act introduced a provision, in Article 6e, that regulated relation of the National Bank with other banks. According to this article, the National Bank was allowed to advance credits only to those banks whose lending rates were up to $3 \%$ higher than the National Bank's interest rate for private borrowers. ${ }^{43}$ In essence, Article 6e introduced an interest rate ceiling as a legal instrument of monetary policy. It was proposed by the government as a measure to force banks to keep their lending rates at the levels near the National Bank's discount rate.

\footnotetext{
$41 \quad$ Dugalić, V. (1999): Narodna banka 1884-1941, Jugoslovenski pregled, Beograd, p. 65.

42 Capie, F., Goodhart, C. and Schnadt, N. (1994): p. 69.

43 Dugalić, V. (1999): p. 96.
}

Vol. 14, № 2, 2017: 1-22 
Table 7. National Bank Credits - Total and to Banks 1884-1913 in mill. dinars

\begin{tabular}{|c|c|c|c|c|}
\hline \multirow{2}{*}{ Year } & \multirow{2}{*}{ Total credits } & \multicolumn{3}{|c|}{ Credits given to the banks } \\
\hline & & Number of banks & Amount & $\%$ of total credits \\
\hline 1884 & 3,669 & - & - & - \\
\hline 1885 & 5,938 & 15 & 1,380 & 23,2 \\
\hline 1886 & 6,814 & - & 1,810 & 26,4 \\
\hline 1887 & 8,939 & - & 2,152 & 24,0 \\
\hline 1888 & 10,334 & 31 & 2,755 & 26,6 \\
\hline 1889 & 11,915 & 38 & 4,064 & 34,1 \\
\hline 1890 & 12,929 & 38 & 4,778 & 36,9 \\
\hline 1891 & 15,689 & 39 & 6,193 & 39,4 \\
\hline 1892 & 16,133 & 41 & 5,617 & 34,8 \\
\hline 1893 & 16,126 & 43 & 5,872 & 36,4 \\
\hline 1894 & 14,297 & 48 & 4,714 & 32,9 \\
\hline 1895 & 13,996 & 48 & 4,858 & 34,7 \\
\hline 1896 & 12,451 & 49 & 4,220 & 33,9 \\
\hline 1897 & 12,331 & 50 & 4,334 & 35,1 \\
\hline 1898 & 13,278 & 51 & 4,769 & 35,9 \\
\hline 1899 & 13,833 & 58 & 5,089 & 36,8 \\
\hline 1900 & 14,204 & 58 & 5,283 & 37,2 \\
\hline 1901 & 14,888 & 61 & 5,461 & 36,7 \\
\hline 1902 & 16,031 & 64 & 5,909 & 36,8 \\
\hline 1903 & 16,400 & 67 & 6,581 & 40,1 \\
\hline 1904 & 17,692 & 71 & 7,492 & 42,3 \\
\hline 1905 & 18,945 & 76 & 8,042 & 42,4 \\
\hline 1906 & 20,912 & 83 & 9,541 & 45,6 \\
\hline 1907 & 22,715 & 84 & 11,450 & 50,4 \\
\hline 1908 & 29,485 & 101 & 16,635 & 56,4 \\
\hline 1909 & 26,560 & 57 & 13,207 & 49,7 \\
\hline 1910 & 33,451 & 58 & 16,823 & 50,3 \\
\hline 1911 & 40,858 & 58 & 20,900 & 51,1 \\
\hline 1912 & 45,401 & 69 & 27,190 & 59,9 \\
\hline 1913 & 49,743 & 68 & 31,175 & 62,6 \\
\hline
\end{tabular}

Source: 1.Godišnji izveštaj Privilegovane Narodne Banke Kraljevine Srbije, various years. 


\section{Figure 1}

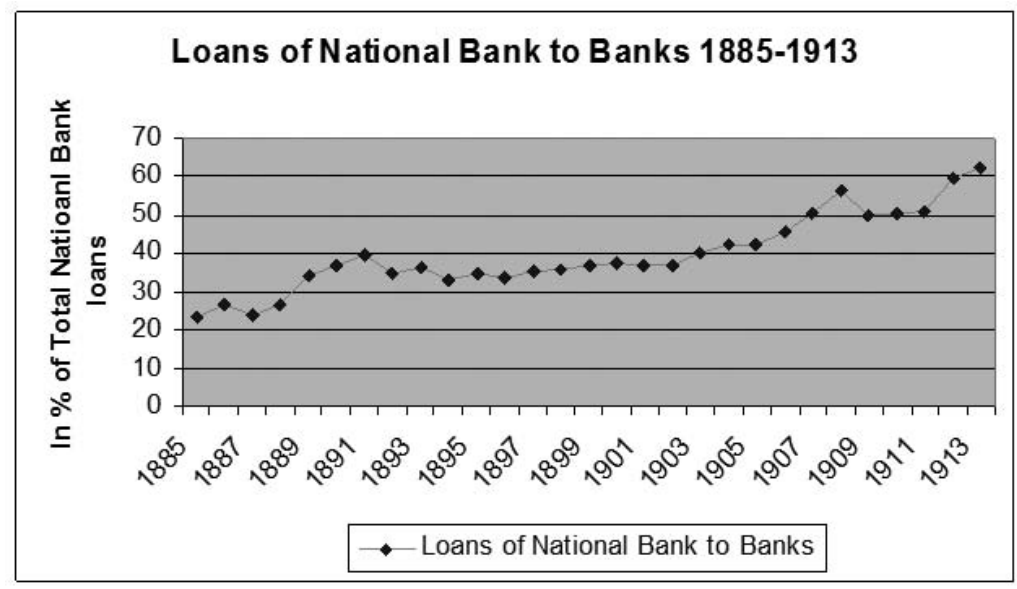

Source: Table 7.

The introduction of Article 6e was an innovation in monetary legislation and policy because it legally defined the relation of the National Bank with other banks, thus becoming obligatory for both the National bank and private banks through the instrument of interest rate ceiling.

The National Bank itself was against this regulation arguing that it would be counterproductive in practice. It really turned out that application of Article $6 \mathrm{e} \mathrm{had}$ two negative consequences. Firstly, it added additional pressure to already rising market interest rates, and secondly, it severely harmed relations of the National Bank with other banks since many banks stopped cooperating with the National Bank.

\section{Figure 2}

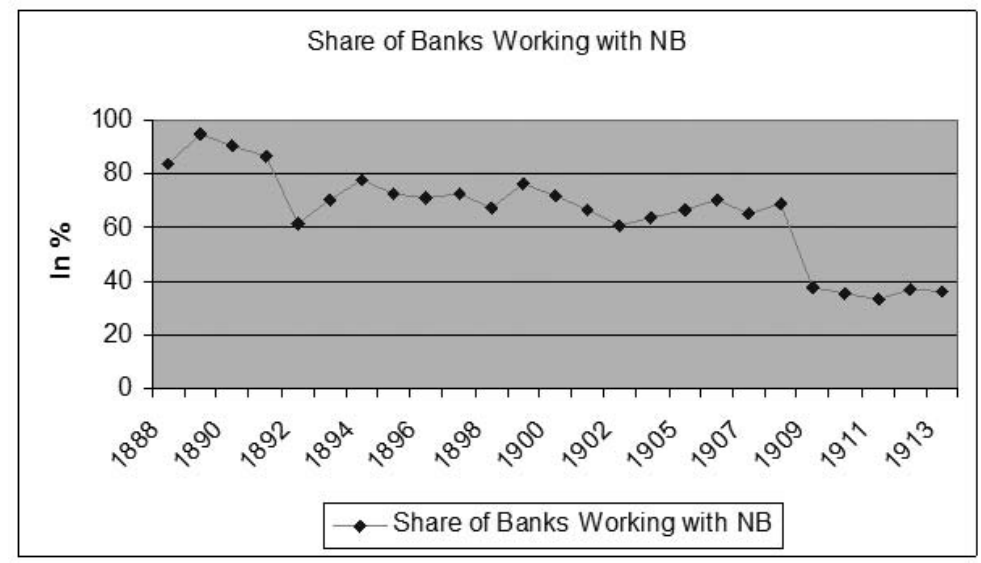

Source: Table 7.

Vol. 14, № 2, 2017: 1-22 
Before the adoption of the new legislation in 1908, some 101 banks had been in relations with the National Bank while this number dropped to 57 in 1909 (Table 7). After 1908, only about less than $40 \%$ of the banks continued to work with the National Bank (Figure 2). Thus, the enacted government's decision to implement interest rate ceiling prevented the National Bank to continue strengthening its role as a central bank.

The National Bank several times appealed to the government for revoking the Article 6e, but these attempts remained unaccepted. Then, in 1911, the National Bank proposed bank mergers as an appropriate method for decreasing unhealthy competition among too many small banks, which was one of the main causes of high market interest rates. This time the government positively responded by taking the National Bank's proposal into consideration. At that time, apart from mergers of existing banks, reduction of competition among the banks could be achieved also with other methods - by limiting entry into banking with various legal rules (charters, licenses) or by establishing capital requirements that are so high that they can be met only by small number of institutions. ${ }^{44}$ Instead of bank mergers, as proposed by the National Bank to stifle bank competition, Serbian government chose capital requirement as a method to prevent too small banks to be created in the future. It was enacted by the Ministry of the National Economy that prescribed minimum capital requirements for the establishment of the joint-stock banks. According to this new regulation, the minimum authorized capital of one million dinars was required for establishing banks in Belgrade and half million dinars for banks in provinces. Additionally, the deadline for complete, full payment of the minimum capital requirement was clearly defined - the capital had to be paid-up within two years without dividing it into many small installments. In the light of this new regulation, already existing banks were left with two options: to meet the minimum capital requirement as required or to go into liquidation. Some of the banks began to increase their paid-up capital during the first half of 1914, but the outbreak of World War I interrupted this process and further development of the Serbian banking system.

$44 \quad$ Grossman S., R. (2010): p. 131. 


\section{Conclusion}

The majority of private banks were small joint-stock unit and universal banks. They engaged themselves in banking and non-banking activities. Banks developed all the main banking operations of the time - taking savings deposits, discounting, active and passive current accounts. Less developed were cashless payment and lombard operations backed by securities. Trade in securities accounted to only a small share of banking operations due to the absence of developed money and capital markets. Among non-banking activities, banks were engaged in conducting domestic and foreign trade and in establishing and running industrial firms that was of the vital importance for the first stage of industrialization in the Kingdom of Serbia.

The relations between the banks and the National Bank had been developing, i.e. intensifying by 1908 on the voluntary basis, primarily by the National Bank's everyday credit operations, undertaken rules and measures that created national banking system. This system functioned relatively smoothly with strengthening central position of the National bank. In this regard, especially effective were the National Bank's instruments of preferential discount rates for banks and rules about banks' lending rates. From 1908, however, these relations were regulated by the new Act on the National Bank (1908) through the instrument of interest rate ceiling (Article 6e) and thus became obligatory for both parties. Unfortunately, implementation of this act led to deteriorating relations between the banks and the National Bank thus preventing the National Bank to continue with strengthening its role as a central bank.

The Serbian National Bank succeeded in successfully fulfilling the main aims of a central bank. Firstly, it achieved monetary stability by maintaining convertibility of its banknotes and legal cover of the quantity of money in circulation (defined at the minimum level of $40 \%$ ). Secondly, it contributed to economic development by maintaining stable and relatively low (for Serbian economic circumstances) discount rates. However, in achieving stability of the banking system it was limited because it could not fully perform its lender of the last resort function - to lend unlimited amounts backed by good quality paper on a penalty rate. This function was constrained, not by unwillingness or incapability of the National bank, but by its two legal obligations - to maintain legal cover and to respect limited issue of the silver notes i.e. credits in silver. Perhaps, this is the reason why the Serbian National Bank was excluded from the group of fully-fledged central banks given in Table 1. During two systemic banking crises that took place in 1908 and 1912, since the National Bank did not have the capability of unlimited lending, rescue operations were also taken by the State (the Ministry of Finance and Ministry of the National Economy) which helped the National Bank to continue lending in order to contain withdrawals from the banks. Thus, both banking crises were successfully managed by the concerted actions of the National Bank and the Serbian state. ${ }^{45}$

Stojanović, B. (2010): p. 287.

Vol. 14, № 2, 2017: 1-22 


\section{Literature}

- $\quad$ AS, Zbornik zakona, 1904, Zbornik 59.

- Blancheton, B. (2015): Towards a tacit low-degree independence central banking model, Cahiers du GREThA, No 2015-17, Universite de Bordeaux, France.

- Capie, F., Goodhart, C. and Schnadt, N. (1994): The development of central bankning, in: Capie, F. et al. (eds.), The Future of central banking: the tercentenary symposium of the Bank of England, Cambrodge UK:Cambridge University Press, pp.1-261, ISBN 9780521496346

- Dugalić, V. (1999): Narodna banka 1884-1941, Jugoslovenski pregled, Beograd.

- CCirović, M., (2001): Bankarstvo, Bridge Company, Beograd.

- Godišnji izveštaj Privilegovane Narodne Banke Kraljevine Srbije, (1884).

- Godišnji izveštaj Privilegovane Narodne Banke Kraljevine Srbije, (1885).

- Godišnji izveštaj Privilegovane Narodne Banke Kraljevine Srbije, (1890).

- Građanski zakonik za Kraljevinu Srbiju, 1891.

- Grossman, S.R., (2010): Unsettled Account, The Evolution of Banking in the Industrialized World since 1800, Princeton University Press, Princeton and Oxford.

- Kukla, S. (1924): Razvitak kreditne organizacije u Srbiji do svetskog rata, Komisiona naklada Hr. Štamp. Zavod D.D., Zagreb.

- Milić, Dr D., (1994): Monetarno-kreditni sistem u privredi Srbije početkom $X X$ veka, in: Srbija u modernizacijskim procesima XX veka, Institut za noviju istoriju Srbije, Beograd.

- Narodna banka 1884-1909, (1909): Štampano u novoj štampariji - DavidovićLjub. M. Davidovoća, Beograd.

- Narodna banka 1884-1934, (1934): Zavod za izradu novčanica Topčider.

- Smith, V. (1990): The Rationale of Central Banking and the Free Banking Alternative, Liberty Fund, Indianopolis, ISBN 0-86597-086-6.

- Stanarević, Nik. (1912): Beogradske banke u 1911, Štamparija Sv. Sava, Beograd.

- Stojanović, B. (1992): Iz ekonomsko-finansijske i političke istorije Srbije (18781918): Finansije, broj 3-4, Beograd.

- Stojanović, B. (2010): The banking Crises in the Kingdom of Serbia in 1908 and 1912, Scientific Annals of Economics and Business, Volume LVII, Alexandru Ioan Cuza University of Iosi, Romania, ISSN: 0379-7864.

- Stojanović, B. (2017): The rise and growth of Serbian banking until World War I, Part Two: The Second stage - The National State and the Nationala Banking, Megatrend revija/Megatrend Review, Vol14 (1)

- White, E.N. (1998): Were Banks Special Intermediaries in Late Nineteenth Century America?, Federal Reserve Bank of St. Louis, May/June.

- Zakon o Narodnoj banci, 6. Januar, 1883. god. 


\author{
Prof. dr Biljana Stojanović \\ Geoekonomski fakultet, Univerzitet Džon Nezbit, Beograd
}

\title{
NASTANAK I RAST SRPSKOG BANKARSTVA DO PRVOG SVETSKOG RATA Treći deo: \\ Srpski bankarski sistem- operacije i odnosi privatnih banaka i Narodne banke (1878-1914)
}

Razvoj srpskog bankarstva tokom 19. veka je bio postepen process koji se odvijao u dve faze sa prekretnicom 1878. godine, kada je medunarodnim ugovorom Srbiji priznat status nezavisne države na Berlinskom kongresu.

U drugoj fazi, posle 1878. godine, odlučan program ekonomskog razvoja i modernizacije doveo je do velikog porasta banaka i stvaranja nacionalnog bankarskog sistema koji se sastojao od Privilegovane banke Kraljevine Srbije (Narodna banka) kao emisione banke, privatnih banaka, državnih banaka i seljačkih zadruga. Većina privatnih banaka su bila mala akcionarska društva bez filijala, univerzalnog tipa, koje su razvile osnovne bankarske aktivnosti (diskontovanje, štedne depozite, pasivne i aktivne tekuće račune, lombardne kredite, bezgotovinska plaćanja, trgovinu efektima) kao i nebankarske poslove (osnivanje industrijskih preduzeća,vođenje domaće i spoljne trgovine).

Odnosi između banaka i Narodne banke su se pojačavali do 1908. godine na dobrovoljnoj bazi, prevashodno kreditnim operacijama, pravilima i merama Narodne banke. Medutim, od 1908. godine, te odnose je regulisao novi Zakon o Narodnoj Banci (1908) preko instrumenta limitiranja kamatnih stopa (Član 6e) koji je postao obavezan za obe strane. Nažalost, sprovodenje ovog novog instrumenta je dovelo do slabljenja odnosa izmedu banaka i Narodne Banke, što je onemogućilo Narodnu Banku da nastavi sa jačanjem svoje uloge kao centralne banke.

Srpska Narodna banka je uspešno sprovela dva snovna cilja centralne banke - monetarnu stabilnost i potpomaganje razvoja nacionalne trgovine i proizvodnje, posebno industrije. Međutim, u postizanju stabilnosti bankarskog sistema bila je ograničena, zato što nije mogla u potpunosti da obavlja funkciju kreditora u poslednjoj instanci. Ograničenost u ovoj funkciji nije bila posledica nesklonosti ili nesposobnosti Narodne banke, već njene dve zakonske obaveze - održavanja zakonskog pokrića i poštovanja limita emisije srebrnih novćanica, tj.kredita u srebru. Stoga su dve sistemske bankarske krize koje su se desile 1908 i 1912. godine, uspešno prevaziđene zajedničkim delovanjem Narodne Banke i srpske države .

Ključne reči: banke, Narodna banka, nacionalni bankarski sistem, diskontna stopa, kreditor u poslednjoj instanci 
